\title{
Preharvest and Postharvest Factors Affecting the Quality and Shelf Life of Harvested Tomatoes: A Mini Review
}

\author{
Isaac Kojo Arah, ${ }^{1}$ Harrison Amaglo, ${ }^{1}$ Ernest Kodzo Kumah, ${ }^{2}$ and Hayford Ofori ${ }^{1}$ \\ ${ }^{1}$ Department of Agricultural Engineering, Ho Polytechnic, P.O. Box HP217, Ho, Ghana \\ ${ }^{2}$ Department of Agro-Enterprise Development, Ho Polytechnic, P.O. Box HP217, Ho, Ghana
}

Correspondence should be addressed to Isaac Kojo Arah; isaacarah@gmail.com

Received 14 October 2015; Accepted 29 November 2015

Academic Editor: Allen Barker

Copyright (C) 2015 Isaac Kojo Arah et al. This is an open access article distributed under the Creative Commons Attribution License, which permits unrestricted use, distribution, and reproduction in any medium, provided the original work is properly cited.

\begin{abstract}
Tomato production can serve as a source of income for most rural and periurban producers in most developing countries of the world. However, postharvest losses make its production unprofitable in these parts of the world. Postharvest losses in tomatoes can be as high as $42 \%$ globally. Postharvest losses in tomatoes can be either quantitative or qualitative. Even though emphasis in crop research nowadays is increasing shifting from quantity to quality of produce, there is still little improvement in the quality of commercially produced tomato varieties, hence resulting in high quality losses. From the study it was discovered that the postharvest quality status of tomatoes partly depended on some preharvest practices carried out during production. Some of these factors are fertiliser application, pruning, maturity stage, cultivar selection, and irrigation. Using best postharvest handling practices or factors such as temperature, relative humidity, gases in storage, postharvest calcium chloride application, and physical handling procedures to maintain the quality after harvest was also critical. It was concluded by this study that understanding and managing both preharvest and postharvest factors properly will reduce the postharvest quality losses in tomatoes.
\end{abstract}

\section{Introduction}

Tomato is one of the most popular produced and extensively consumed vegetable crops in the world [1]. Tomatoes can be consumed in many ways. The fresh fruits are eaten in salads and sandwiches and as salsa whilst the processed ones are consumed dried or as pastes, preserves, sauces, soups, juices, and drinks $[2,3]$. Tomatoes and tomato-based foods provide a wide variety of nutrients and many health-related benefits to the body. Tomato contains higher amounts of lycopene, a type of carotenoid with antioxidant properties [4] which is beneficial in reducing the incidence of some chronic diseases [5] like cancer and many other cardiovascular disorders [6]. In regions where it is being cultivated and consumed, it constitutes a very essential part of people's diet. Tomatoes production accounts for about 4.8 million hectares of harvested land area globally with an estimated production of 162 million tonnes [7]. China leads world tomato production with about 50 million tonnes followed by India with 17.5 million tonnes [7]. Tomato production can serve as a source of income for most rural and periurban producers in most developing countries of the world [8]. Despite the numerous benefits that can be derived from the crop, postharvest losses make its production in most parts of the world unprofitable. Postharvest losses in tomatoes can be as high as $25-42 \%$ globally [9]. These losses bring low returns to growers, processors, and traders as well as the whole country which suffers in terms of foreign exchange earnings [10].

Postharvest losses in tomatoes can be either quantitative or qualitative. Even though emphasis in crop research nowadays is increasing shifting from quantity to quality of produce [11] there is still little improvement in the quality of commercially produced tomato varieties [3], hence resulting in high amount of qualitative losses. However, qualitative loss in tomato production can have a negative impact on many parameters like consumer acceptability, nutrient status of fruits, and financial income to producers. An investigation into the possible factors that can affect the postharvest quality of tomatoes is therefore necessary. The postharvest qualities of tomatoes are dependent not only on postharvest handling and treatment methods but also on many preharvest factors 
such as genetic and environmental conditions [12]. Many cultural practices such as types of nutrient, water supply, and harvesting methods are also believed to be factors influencing both pre- and postharvest quality of tomato [13]. Many postharvest quality losses are as a result of many preharvest factors [14]. Tomato fruits that are diseased and infected by pest, inappropriately irrigated, and fertilised or generally of poor quality before harvesting can never be improved in quality by any postharvest treatment methods [15]. This indicates that the postharvest quality of the fruit cannot be improved after harvest but can only be maintained. It is therefore important to know the preharvest factors that can produce superior qualities in fruits during harvest whilst using appropriate postharvest handling and treatment methods to maintain the quality after harvest. The purpose of this paper therefore is to look at some preharvest and postharvest factors and how they can affect the postharvest qualities and shelf life of harvested tomatoes.

\section{Preharvest Factors Affecting the Postharvest Quality of Tomatoes}

Below are some preharvest factors or activities that can affect the postharvest shelf life and qualities of harvested tomato fruits.

2.1. Fertiliser Application. Consumers in the past few decades have become increasingly concerned about the quality of the food products they are consuming. Researchers have therefore investigated the impact of plant nutrition on the quality of fruits produced. The quality traits required or purpose for which the crop is grown will help in selecting not only the type of fertiliser but the quantity used during production. For instance, an adequate supply of potassium fertilizer in tomato production improves fruit colour and reduces the incidence of yellow shoulder [16], whilst enhancing the titratable acidity of the fruit [17]. Yellow shoulder is a physiological disorder of tomatoes that is characterized by discoloured regions that border the stem scar. Insufficient supply of potassium in soilless tomato production can also result in ripening disorders [18]. Unlike potassium, an increase in nitrogen supply to greenhouse-grown tomatoes, beyond a certain threshold level, may reduce fruit quality by decreasing the sugar content of the fruits [17]. High nitrogen supply of about $250 \mathrm{~kg} / \mathrm{ha}$ can impair some important quality traits of fruits, such as total soluble solids [19], glucose, fructose, and $\mathrm{pH}$ [20]. A supply of reduced forms of nitrogen, such as ammonium, can result in improved fruit flavours [21]. However, the variation of phosphorus supply in soils for growing tomato crops does not significantly influence quality traits such as the total soluble solids [19], $\mathrm{pH}$, acidity of the tomato juice, or the fruit colour characteristics [22]. For trace elements use, the quality of tomato fruit is affected predominantly by the amount of boron used, although other micronutrients may affect fruit quality only when the plants show severe deficiency symptoms. Lower amounts of boron supply reduce fruit firmness which is of major concern during storage [23]. Calcium application in tomato production has recently been studied and found to have a positive effect on the prevention of some diseases [17], whilst slowing the reduction in fruit firmness during ripening. Spraying tomato leaves with different combinations of calcium salts is effective in controlling powdery mildew on the crop [24]. Also an enhanced supply of calcium significantly increases the resistance to bacterial wilt caused by Ralstonia solanacearum in tomato [25]. Calcium can be applied to the root zone in the soil or sprayed on the leaves [26]. The type of application is determined by the growth stage of the crop and type of disease prevalent. Postharvest calcium application can also have a positive storage effect in calcium deficient harvested fruits [27, 28].

2.2. Pruning. Controlling the number of flowers, fruits, or fruit trusses in tomatoes is an effective way of reducing the competition between fruits. Pruning therefore ensures nutrients are channelled to fewer fruits sinks which can lead to increased fruit size [29] whilst increasing sugar content of fruits in some cases [30]. Pruning clusters to three fruits increased total marketable yield and fruit weight and reduced cull yield of all cultivars under investigation [31]. Meanwhile, the effect of pruning on other quality traits of the fruit produced depends on many factors including the sink developmental stage, fruit to leaf ratio, truss position, and genetic background [29]. Pruning can result in increased fruit size in most cultivars, under the right growing conditions, and thus can be used to improve the marketability of high total soluble solids (TSS) fruits which in most cases tend to be smaller in size [3]. Larger fruits which are within a certain size range are usually considered to be of better value by most consumers.

2.3. Maturity Stage. The maturity stage of tomato fruit at harvest is an important determinant of many quality traits [3]. Tomato, being a climacteric fruit, can be harvested at different stages during maturity, like mature green, half ripen, or red ripen stage. Each stage at harvest has its own postharvest attribute that the fruit will exhibit. Moneruzzaman et al. [32] reported that the shelf life of all tomato cultivars under investigation is longest when harvested at green mature stage. Although shelf life has been the most important aspect in loss reduction biotechnology of fruit and vegetables, other aspects may be of interest rather than shelf life. Fruit nutritional values and appearance may be affected when harvested green. For instance, sugar transport to fruits in a vine-ripened tomato appears to increase during the latter part of maturity [33] and, therefore, when fruits are harvested immature or in a green state sugar import to fruits will be cut off making postharvest degradation of starch, the main source of carbohydrates, which is both undesirable and inadequate [34]. Meanwhile, harvesting later also promotes higher sugar accumulation in riper fruits which are susceptible to mechanical injuries with a shorter shelf life [35]. The pH of tomatoes is an important parameter in the tomato processing industry. Tomatoes are processed as high-acid foods and therefore the higher the acidity the better for processing. Cultivars with high $\mathrm{pH}$ therefore may not be suitable for processing. A pH of 4.4 has been suggested to be the maximum and the optimum of a target of 4.25 [36]. The acidity of tomatoes is highest at the pink stage of maturity with a rapid decrease as the fruit ripens. Moneruzzaman et al. [32] and Cliff et al. [37] 
suggested tomato fruits can be harvested at mature green to give producers enough time for long distance marketing but for local marketing harvesting at the fully ripe stage is preferred to maximise nutritional value.

2.4. Cultivar Type. The potential quality of fruit is dependent on the cultivar type. Different cultivars are characterised by different quality parameters making some more desirable to the producers and consumers than others. The choice of an adequate-yielding tomato cultivar with desired fruit qualities and longer shelf life is therefore a vital decision a producer must take [31]. Failure to select an appropriate cultivar may lead to lower yield, low quality fruits, or less market acceptability. Fruits of different cultivars differ in size, colour, texture, and flavour as well as storage potential. Getinet et al. [38] report the influence of tomato cultivar on some postharvest qualities of tomatoes stored under different conditions. Getinet et al. [39] established that tomato cultivar Roma VF has higher sugar content whilst maintaining lower weight loss as compared to cultivar Marglobe. Cultivar selection is therefore critical to the postharvest storage life and eating qualities of tomatoes.

2.5. Irrigation. Tomato is not a drought resistant crop and therefore yields decrease considerably after short periods of water deficiency during production. Proper irrigation scheduling in tomato production is therefore crucial to the crop development. However, with water being a scarce resource in most production areas, growers in recent years have therefore had to develop a more efficient water management scheme that maintains crop yield but has a moderate and controlled level of moisture stress on their crops. In a study conducted by Mitchell et al. [40], it was revealed that deficit irrigation reduced fruit water accumulation and fresh fruit yield but increased fruit total soluble solids [19] levels. They also discovered that irrigating with saline water had no significant effect on total fruit yield but moisture content of fruits was slightly reduced. Ismail et al. [41] also established that early morning irrigation every three days resulted in higher yields than daily irrigation. The use of trace elements or the practice of soilless tomato production can be made possible during irrigation where the fertilisers (trace elements) are added to the irrigation water in a form of solution and administered. These trace elements are selected depending on the specific postharvest quality traits needed in the fruits.

\section{Postharvest Factors Affecting the Postharvest Quality of Tomatoes}

After harvesting, the fruit still remains alive and performs all functions of a living tissue. The climacteric burst of ethylene which makes the fruit palatable also triggers senescence and subsequent ripening in the fruits. The goal of any postharvest handling practice or treatment is to manage the concentration and timing of ethylene synthesis so that the fruit reaches the consumer at optimal eating quality [3]. The following factors discussed below can affect the quality of tomatoes after harvest when not properly managed.
3.1. Temperature. Proper temperature management between the period of harvesting and consumption has been found to be the most effective way to maintain quality. Keeping harvested fruits cool at low temperatures of about $20^{\circ} \mathrm{C}$ will slow down many metabolic activities which lead to ripening, hence allowing more time for all the postharvest handling of the produce. Generally, one hour of delay between harvesting the crop and cooling it will lead to one day loss of shelf life [42, 43]. Respiration and metabolic activities within harvested climacteric fruits like tomatoes are directly related to the temperatures of the ambient environment. High temperatures can hasten the rate of respiration $\left(\mathrm{CO}_{2}\right.$ production) in harvested or stored fruits products. $\mathrm{CO}_{2}$ production in stored climacteric products like tomatoes can trigger ethylene production although this depends on other factors like $\mathrm{O}_{2}$ or $\mathrm{CO}_{2}$ levels, exposure time, and ripening stage [44]. Minute amounts of ethylene can cause ripening in fruits even at levels of tens of $\mathrm{nL}$ per L [45]. Heat stored in field-harvested fruits is a major source of high temperatures in fruits. The time of the day at which harvesting is done must therefore be considered to avoid excessive field heat which can cause more rapid deterioration in the harvested fruits.

Low temperature storage can protect nonappearance quality attributes like texture, nutrition, aroma, and flavour [43]. Meanwhile, tomato being a tropical fruit is also adversely affected by exposure to extremely low temperatures. Chilling injury can occur in tomato fruits stored at temperatures below $10^{\circ} \mathrm{C}[46]$. The effect of chilling injury includes premature softening, irregular colour development, surface pitting, browning of seeds, water-soaked lesions, off-flavour development, and increased postharvest decay [47]. It is therefore important to determine the optimum temperature needed when handling tomato fruits during storage.

3.2. Relative Humidity. Water loss from harvested fruit produce is predominantly caused by the amount of moisture present in the ambient air expressed as relative humidity [48]. At very high relative humidity, harvested fruits maintain their nutritional quality, appearance, weight, and flavour, whilst reducing the rate at which wilting, softening, and juiciness occur. Tomato fruits are very high in water content and susceptible to shrinkage after harvest. Fruit shrivel may become evident with any small percentage of moisture loss. The optimal values of relative humidity for mature green tomatoes are within the range of $85-95 \%(\mathrm{v} / \mathrm{v})$ but $90-$ $95 \%(\mathrm{v} / \mathrm{v})$ for firmer ripe fruits [49]. Below the optimal range, evapotranspiration increases resulting in shrivelled fruits. Storage of tomato fruit at a lower relative humidity can result in shrivelling. Addition of moisture (wetting fruits) in lower relative humidity storage can reduce weight loss and prevent fruit from shrivelling. Meanwhile, completely saturated atmospheres of $100 \%$ relative humidity should be avoided, as moisture condensation on the fruit surfaces may encourage mould and fungal development.

3.3. Combination Gases. The combination of different gases in a storage environment is very important in extending the storage life of tomato fruits. The optimal atmosphere needed to inhibit senescence in mature green and ripe fruit 
of tomatoes is $3-5 \%(\mathrm{v} / \mathrm{v})$ of oxygen but for carbon dioxide it is $1-3 \%(\mathrm{v} / \mathrm{v})$ and $1-5 \%(\mathrm{v} / \mathrm{v})$ in mature green and ripe fruit, respectively [50], whilst $94-96 \%(\mathrm{v} / \mathrm{v})$ of nitrogen gas is required [51]. A very low supply of oxygen can have a detrimental effect on fruits by causing anaerobic respiration [52]. Carbon monoxide (CO) has been investigated as a gas for treating fruits and has been found to speed up ripening [3]. It is therefore necessary to balance the carbon monoxide with low oxygen to delay senescence in the fruits [53]. Carbon monoxide slows down postharvest pathogenic infestations whilst improving some quality traits of tomatoes. For instance, tomatoes stored in $5-10 \%(\mathrm{v} / \mathrm{v})$ carbon monoxide with $4 \%(\mathrm{v} / \mathrm{v})$ oxygen were found to have superior total soluble solids (TSS) and titratable acid (TA) profiles as compared to control samples stored in air [53]. The use of carbon monoxide in the food industry is however complicated because of its health hazards to humans and must be used with great caution.

3.4. Postharvest Calcium Chloride Application. Higher plants generally contain appreciable amounts of calcium, usually in the range of $1-50 \mathrm{mg} \mathrm{Cag}^{-1}$ dry matter [27]. Calcium deficiency in plants can be minimised using calcium based fertilisers. Calcium deficiency in tomato during fertilisation can result in susceptible plants which are exposed to many calcium related disorders like blossom end rot [29, 54]. Calcium has been found to increase the yield of tomato when used as a fertilizer [55]. Postharvest calcium application has also been shown to have a positive effect on many storage parameters of various fruits and vegetables. For instance, the use of calcium chloride in controlling rapid ageing in harvested fruits in general has been investigated by many authors [56-58]. Postharvest calcium chloride application reduces respiration, decreases ethylene production, and delays senescence in fresh produce such as tomatoes [59]. Exogenous application of calcium maintains cell-wall integrity and protects it from degrading enzymes [60], enhancing better linkages between pectic substances within the cell-wall whilst increasing the cohesion of cell-walls [61]. This therefore gives an indication that the rate of senescence in fruits is closely related to the amount of calcium in the plant tissue and varying the calcium status affects the rate of senescence. It has been established that altering the levels of exogenous calcium application affects parameters for senescence such as protein and chlorophyll content, respiration rates, and cell membrane fluidity [62]. Kwon et al. [63] also note that addition of calcium rigidifies cell-wall and obstructs enzymes such as polygalacturonase from reaching active sites.

3.5. Physical Handling. Physical handling can have a drastic effect on the postharvest quality or life of harvested fruits. Rough handling during harvesting and after harvesting can result in mechanical injuries which affect quality. Typical industrial production systems associated with tomatoes may include mechanical harvesting, packing into crates, sorting, grading, washing, and transporting over long distances. At each of these stages there may be significant occurrence of mechanical injury which may be bruising, scarring, scuffing, cutting, or puncturing the fruits. In small-scale tomato production, mechanical injuries may result from the use of inappropriate harvesting containers and packaging materials. According to Miller [64], the effects of mechanical injuries on fruit are cumulative. Injuries which are equivalent to or greater than the bioyield point lead to a total breakdown of the structure of the affected cells which is accompanied by unwanted metabolic activities which may include increased ethylene production, accelerated respiration rates, and ripening $[64,65]$, which results in either reduced shelf life or poor quality. It is therefore important to handle tomato fruit with care during the harvest and postharvest activities to minimise mechanical injuries to avoid losses.

\section{Conclusion}

Postharvest quality management of tomatoes starts from the field and continues until it reaches the final consumer. The postharvest quality status of the fruits in part depends on some preharvest practices carried out during production. The quality of any fruit after harvest cannot be improved by the use of any postharvest treatment method or handling practices but can only be maintained. Understanding and managing the various roles that preharvest factors like fertiliser application, pruning, maturity stage, cultivar selection, and irrigation can play in the quality of fruits at harvest is very important in order to produce high quality fruits at harvest. Tomatoes are highly perishable and are subjected to rapid quality loss after harvest. Using best postharvest handling practices or factors such as optimum temperature, right relative humidity, right gases in storage, the use of postharvest calcium chloride application, and the best physical handling procedures to maintain the quality after harvest is also critical. It can be concluded by this study that the quality and storage life of tomatoes after harvest depends on not only the postharvest factors alone but also some preharvest factors during production and, until both factors are managed properly, quality loss will still be a major challenge for tomato producers and handlers.

\section{Conflict of Interests}

The authors declare that there is no conflict of interests regarding the publication of this paper.

\section{References}

[1] S. Grandillo, D. Zamir, and S. D. Tanksley, "Genetic improvement of processing tomatoes: a 20 years perspective," Euphytica, vol. 110, no. 2, pp. 85-97, 1999.

[2] T. Alam, G. Tanweer, and G. K. Goyal, "Packaging and storage of tomato puree and paste," Stewart Postharvest Review, vol. 3, no. 5, pp. 1-8, 2007.

[3] D. M. Beckles, "Factors affecting the postharvest soluble solids and sugar content of tomato (Solanum lycopersicum L.) fruit," Postharvest Biology and Technology, vol. 63, no. 1, pp. 129-140, 2012.

[4] L. Arab and S. Steck, "Lycopene and cardiovascular disease," American Journal of Clinical Nutrition, vol. 71, no. 6, pp. 1691S1695S, 2000. 
[5] A. Basu and V. Imrhan, "Tomatoes versus lycopene in oxidative stress and carcinogenesis: conclusions from clinical trials," European Journal of Clinical Nutrition, vol. 61, no. 3, pp. 295303, 2007.

[6] B. B. Freeman and K. Reimers, "Tomato consumption and health: emerging benefits," American Journal of Lifestyle Medicine, vol. 5, no. 2, pp. 182-191, 2011.

[7] FAOSTAT, Global Tomato Production in 2012, FAO, Rome, Italy, 2014.

[8] I. K. Arah, E. K. Kumah, E. K. Anku, and H. Amaglo, "An overview of post-harvest losses in tomato production in Africa: causes and possible prevention strategies," Journal of Biology, Agriculture and Healthcare, vol. 5, no. 16, pp. 78-88, 2015.

[9] M. ur Rehman, N. Khan, and I. Jan, "Post harvest losses in tomato crop (a case study of Peshawar Valley)," Sarhad Journal of Agriculture, vol. 23, no. 4, pp. 1279-1284, 2007.

[10] A. A. Kader, Post-Harvest Technology of Horticultural Crops, University of California, 1992.

[11] G. O. Oko-Ibom and J. E. Asiegbu, "Aspects of tomato fruit quality as influenced by cultivar and scheme of fertilizer application," Journal of Agriculture, Food, Environment and Extension, vol. 6, no. 1, pp. 71-81, 2007.

[12] G. E. Hobson, "Pre-and post-harvest strategies in the production of high quality tomato fruit," Applied Agricultural Research, vol. 3, no. 5, pp. 282-287, 1988.

[13] M. Melkamu, T. Seyoum, and K. Woldetsadik, "Effects of preand post harvest treatments on changes in sugar content of tomato," African Journal of Biotechnology, vol. 7, no. 8, pp. 11391144, 2008.

[14] R. H. Booth, "Post-harvest deterioration of tropical root crops: losses and their control," Tropical Science, vol. 16, no. 1, pp. 4963, 1974.

[15] J. M. Harvey, "Reduction of losses in fresh market fruits and vegetables," Annual Review of Phytopathology, vol. 16, no. 1, pp. 321-341, 1978.

[16] T. K. Hartz, P. R. Johnson, D. M. Francis, and E. M. Miyao, "Processing tomato yield and fruit quality improved with potassium fertigation," Horticultural Science, vol. 40, no. 1, pp. 1862-1867, 2005.

[17] H. C. Passam, I. C. Karapanos, P. J. Bebeli, and D. Savvas, "A review of recent research on tomato nutrition, breeding and post-harvest technology with refrence to fruit quality," The European Journal of Plant Science and Biotechnology, vol. 1, pp. $1-21,2007$.

[18] P. Adams, "Nutritional control in hydroponics," in Hydroponic Production of Vegetables and Ornamentals, D. Savvas and H. C. Passam, Eds., pp. 211-261, Embryo Publications, Athens, Greece, 2002.

[19] P. A. W. A. N. K. Senevirathna and W. A. M. Daundasekera, "Effect of postharvest calcium chloride vacuum infiltration on the shelf life and quality of tomato (cv. 'Thilina')," Ceylon Journal of Science, vol. 39, no. 1, pp. 35-44, 2010.

[20] M. Parisi, I. Giordano, A. Pentangelo, B. D'Onofrio, and G. Villari, "Effects of different levels of nitrogen fertilization on yield and fruit quality in processing tomato," Acta Horticulturae, vol. 700, pp. 129-132, 2006.

[21] A. Heeb, B. Lundegårdh, T. Ericsson, and G. P. Savage, "Nitrogen form affects yield and taste of tomatoes," Journal of the Science of Food and Agriculture, vol. 85, no. 8, pp. 1405-1414, 2005.

[22] M. Oke, T. Ahn, A. Schofield, and G. Paliyath, "Effects of phosphorus fertilizer supplementation on processing quality and functional food ingredients in tomato," Journal of Agricultural and Food Chemistry, vol. 53, no. 5, pp. 1531-1538, 2005.

[23] J. N. Smit and N. J. J. Combrink, "The effect of boron levels in nutrient solutions on fruit production and quality of greenhouse tomatoes," South African Journal of Plant and Soil, vol. 21, no. 3, pp. 188-191, 2004.

[24] D. L. Ehret, J. G. Menzies, C. Bogdanoff, R. S. Utkhede, and B. Frey, "Foliar applications of fertilizer salts inhibit powdery mildew on tomato," Canadian Journal of Plant Pathology, vol. 24, no. 4, pp. 437-444, 2002.

[25] H. Yamazaki, S. Kikuchi, T. Hoshina, and T. Kimura, "Calcium uptake and resistance to bacterial wilt of mutually grafted tomato seedlings," Soil Science and Plant Nutrition, vol. 46, no. 2, pp. 529-534, 2000.

[26] D. Martínez-Romero, G. Bailén, M. Serrano et al., "Tools to maintain postharvest fruit and vegetable quality through the inhibition of ethylene action: a review," Critical Reviews in Food Science and Nutrition, vol. 47, no. 6, pp. 543-560, 2007.

[27] E. A. Kirkby and D. J. Pilbeam, "Calcium as a plant nutrient," Plant, Cell \& Environment, vol. 7, no. 6, pp. 397-405, 1984.

[28] W. S. Conway, C. E. Sams, and K. D. Hickey, "Pre-and postharvest calcium treatment of apple fruit and its effect on quality," in Proceedings of the International Symposium on Foliar Nutrition of Perennial Fruit Plants, pp. 413-419, Meran, Italy, September 2001.

[29] M. Prudent, M. Causse, M. Génard, P. Tripodi, S. Grandillo, and N. Bertin, "Genetic and physiological analysis of tomato fruit weight and composition: influence of carbon availability on QTL detection," Journal of Experimental Botany, vol. 60, no. 3, pp. 923-937, 2009.

[30] H. Gautier, S. Guichard, and M. Tchamitchian, "Modulation of competition between fruits and leaves by flower pruning and water fogging, and consequences on tomato leaf and fruit growth," Annals of Botany, vol. 88, no. 4, pp. 645-652, 2001.

[31] H. Y. Hanna, "Influence of cultivar, growing media, and cluster pruning on greenhouse tomato yield and fruit quality," HortTechnology, vol. 19, no. 2, pp. 395-399, 2009.

[32] K. M. Moneruzzaman, A. B. M. S. Hossain, W. Sani, M. Saifuddin, and M. Alenazi, "Effect of harvesting and storage conditions on the post harvest quality of tomato," Australian Journal of Crop Science, vol. 3, no. 2, pp. 113-121, 2009.

[33] F. Carrari, C. Baxter, B. Usadel et al., "Integrated analysis of metabolite and transcript levels reveals the metabolic shifts that underlie tomato fruit development and highlight regulatory aspects of metabolic network behavior," Plant Physiology, vol. 142, no. 4, pp. 1380-1396, 2006.

[34] M. E. Balibrea, C. Martínez-Andújar, J. Cuartero, M. C. Bolarín, and F. Pérez-Alfocea, "The high fruit soluble sugar content in wild Lycopersicon species and their hybrids with cultivars depends on sucrose import during ripening rather than on sucrose metabolism," Functional Plant Biology, vol. 33, no. 3, pp. 279-288, 2006.

[35] P. M. A. Toivonen, "Fruit maturation and ripening and their relationship to quality," Stewart Postharvest Review, vol. 3, no. 2, pp. 1-5, 2007.

[36] L. M. Monti, “The breeding of tomatoes for peeling," Acta Horticulturae, vol. 100, pp. 341-349, 1980.

[37] M. Cliff, S. Lok, C. Lu, and P. M. A. Toivonen, "Effect of 1-methylcyclopropene on the sensory, visual, and analytical quality of greenhouse tomatoes," Postharvest Biology and Technology, vol. 53, no. 1, pp. 11-15, 2009. 
[38] H. Getinet, T. Seyoum, and K. Woldetsadik, “The effect of cultivar, maturity stage and storage environment on quality of tomatoes," Journal of Food Engineering, vol. 87, no. 4, pp. 467-478, 2008.

[39] H. Getinet, T. S. Workneh, and K. Woldetsadik, "Effect of maturity stages, variety and storage environment on sugar content of tomato stored in multiple pads evaporative cooler," African Journal of Biotechnology, vol. 10, no. 80, pp. 18481-18492, 2011.

[40] J. P. Mitchell, C. Shennan, S. R. Grattan, and D. M. May, "Tomato fruit yields and quality under water deficit and salinity," Journal of the American Society of Horticultural Science, vol. 116, no. 2, pp. 215-221, 1991.

[41] S. M. Ismail, K. Ozawa, and N. A. Khondaker, "Effect of irrigation frequency and timing on tomato yield, soil water dynamics and water use efficiency under drip irrigation," in Proceedings of the 11th International Water Technology Conference, pp. 15-18, Sharm El-Sheikh, Egypt, March 2007.

[42] M. I. Cantwell, Postharvest Handling of Specialty Vegetables, Department of Vegetable Crops, University of California, Davis, Calif, USA, 1997.

[43] R. E. Paull, "Effect of temperature and relative humidity on fresh commodity quality," Postharvest Biology and Technology, vol. 15, no. 3, pp. 263-277, 1999.

[44] H. P. J. De Wild, E. C. Otma, and H. W. Peppelenbos, "Carbon dioxide action on ethylene biosynthesis of preclimacteric and climacteric pear fruit," Journal of Experimental Botany, vol. 54, no. 387, pp. 1537-1544, 2003.

[45] T. Pranamornkith, A. East, and J. Heyes, "Influence of exogenous ethylene during refrigerated storage on storability and quality of Actinidia chinensis (cv. Hort16A)," Postharvest Biology and Technology, vol. 64, no. 1, pp. 1-8, 2012.

[46] J. K. Raison and J. M. Lyons, "Chilling injury: a plea for uniform terminology," Plant, Cell \& Environment, vol. 9, no. 9, pp. 685686, 1986.

[47] K. Luengwilai, D. M. Beckles, and M. E. Saltveit, "Chillinginjury of harvested tomato (Solanum lycopersicum L.) cv. MicroTom fruit is reduced by temperature pre-treatments," Postharvest Biology and Technology, vol. 63, no. 1, pp. 123-128, 2012.

[48] M. N. Hong, B. C. Lee, S. Mendonca, M. V. E. Grossmann, and R. Verhe, "Effect of infiltrated calcium on ripening of tomato fruits," LWT: Journal of Food Science, vol. 33, pp. 2-8, 1999.

[49] T. V. Suslow and M. Cantwell, "Tomato-recommendations for maintaining postharvest quality," in Produce Facts, A. A. Kader, Ed., Postharvest Technology Research \& Information Center, Davis, Calif, USA, 2009.

[50] F. Artés, P. A. Gómez, and F. Artés-Hernández, "Modified atmosphere packaging of fruits and vegetables," Stewart Postharvest Review, vol. 2, no. 5, pp. 1-13, 2006.

[51] Sandhya, "Modified atmosphere packaging of fresh produce: current status and future needs," LWT-Food Science and Technology, vol. 43, no. 3, pp. 381-392, 2010.

[52] A. A. Kader and M. E. Saltveit, Atmosphere Modification, Marcel Dekker, New York, NY, USA, 2003.

[53] A. A. Kader, "Physiological and biochemical effects of carbon monoxide added to controlled atmospheres on fruits," Acta Horticulturae, vol. 138, pp. 221-226, 1983.

[54] M. C. Saure, "Blossom-end rot of tomato (Lycopersicon esculentum Mill.) — a calcium- or a stress-related disorder?" Scientia Horticulturae, vol. 90, no. 3-4, pp. 193-208, 2001.
[55] A. Akhtar, N. A. Abbasi, and A. Hussain, "Effect of calcium chloride treatments on quality characteristics of loquat fruit during storage," Pakistan Journal of Botany, vol. 42, no. 1, pp. 181-188, 2010.

[56] R. B. H. Wills and S. I. H. Tirmazi, "Effect of calcium and other minerals on ripening of tomatoes," Functional Plant Biology, vol. 6, no. 2, pp. 221-227, 1979.

[57] H. Izumi and A. E. Watada, "Calcium treatments affect storage quality of shredded carrots," Journal of Food Science, vol. 59, no. 1, pp. 106-109, 1994.

[58] A. Prakash, P.-C. Chen, R. L. Pilling, N. Johnson, and D. Foley, " $1 \%$ calcium chloride treatment in combination with gamma irradiation improves microbial and physicochemical properties of diced tomatoes," Foodborne Pathogens and Disease, vol. 4, no. 1, pp. 89-98, 2007.

[59] P. R. Hussain, R. S. Meena, M. A. Dar, and A. M. Wani, "Effect of post-harvest calcium chloride dip treatment and gamma irradiation on storage quality and shelf-life extension of red delicious apple," Journal of Food Science and Technology, vol. 49, no. 4, pp. 415-426, 2012.

[60] P. J. White and M. R. Broadley, "Calcium in plants," Annals of Botany, vol. 92, no. 4, pp. 487-511, 2003.

[61] M. Demarty, C. Morvan, and M. Thellier, "Calcium and the cell wall," Plant, Cell \& Environment, vol. 7, no. 6, pp. 441-448, 1984.

[62] B. W. Poovaiah, "Role of calcium in prolonging storage life of fruits and vegetables," Food Technology, vol. 40, pp. 86-89, 1986.

[63] H. R. Kwon, K. W. Park, and H. M. Kang, "Effects of postharvest heat treatment and calcium application on the storability of cucumber (Cucumis sativus L.)," Journal of the Korean Society for Horticultural Science, vol. 40, pp. 182-187, 1999.

[64] R. A. Miller, "Harvest and handling injury: physiology biochemistry and detection," in Postharvest Physiology and Pathology of Vegetables, J. A. Bartz and J. K. Brecht, Eds., pp. 177-208, Marcel Dekker, New York, NY, USA, 2003.

[65] S. A. Sargent, J. K. Brecht, and J. J. Zoellner, "Sensitivity of tomatoes at mature-green and breaker ripeness stages to internal bruising," Journal of the American Society of Horticultural Science, vol. 117, pp. 119-123, 1992. 


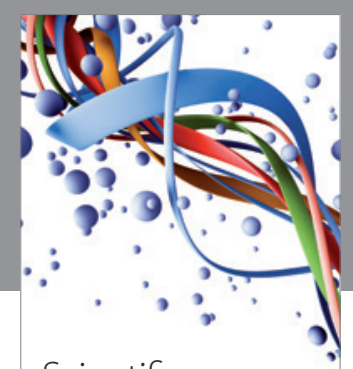

Scientifica
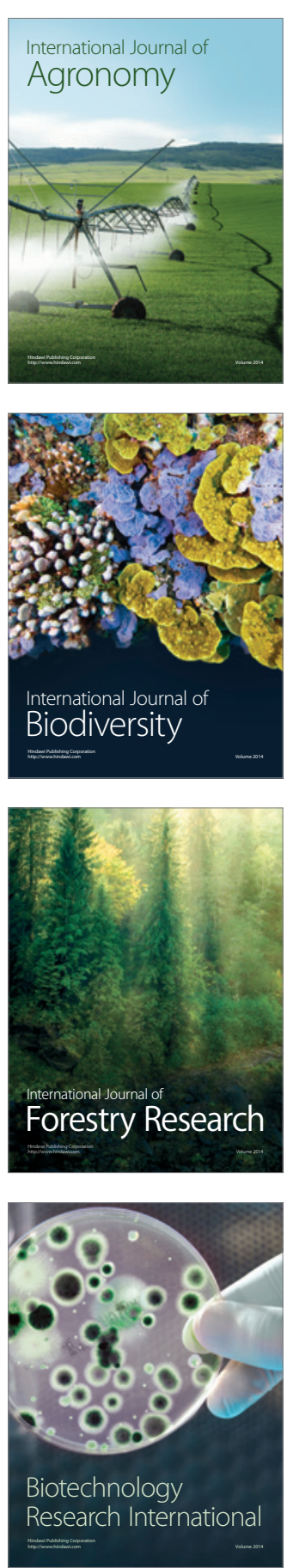
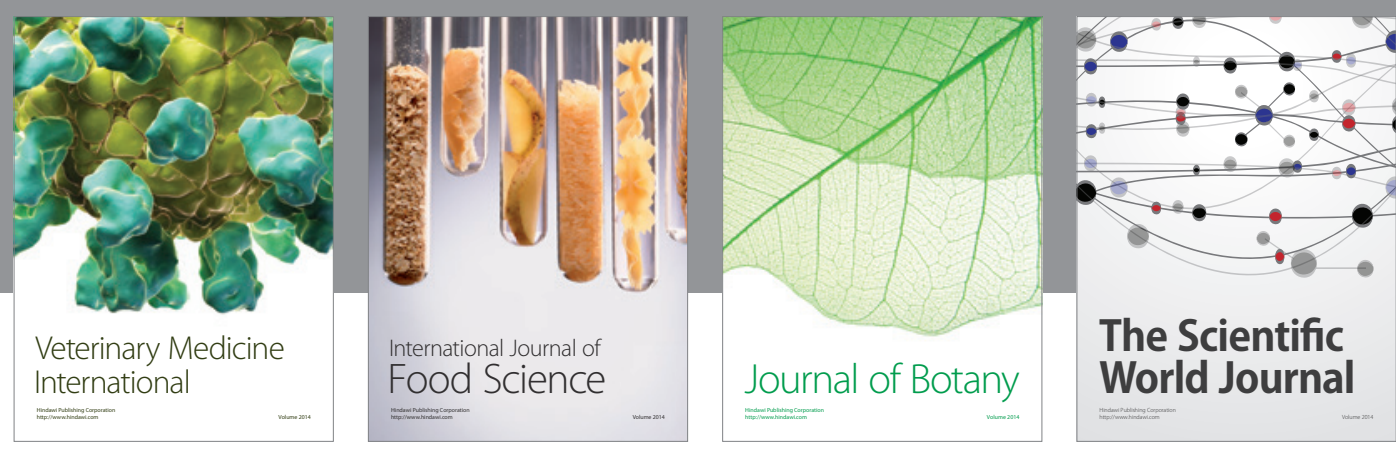

The Scientific World Journal
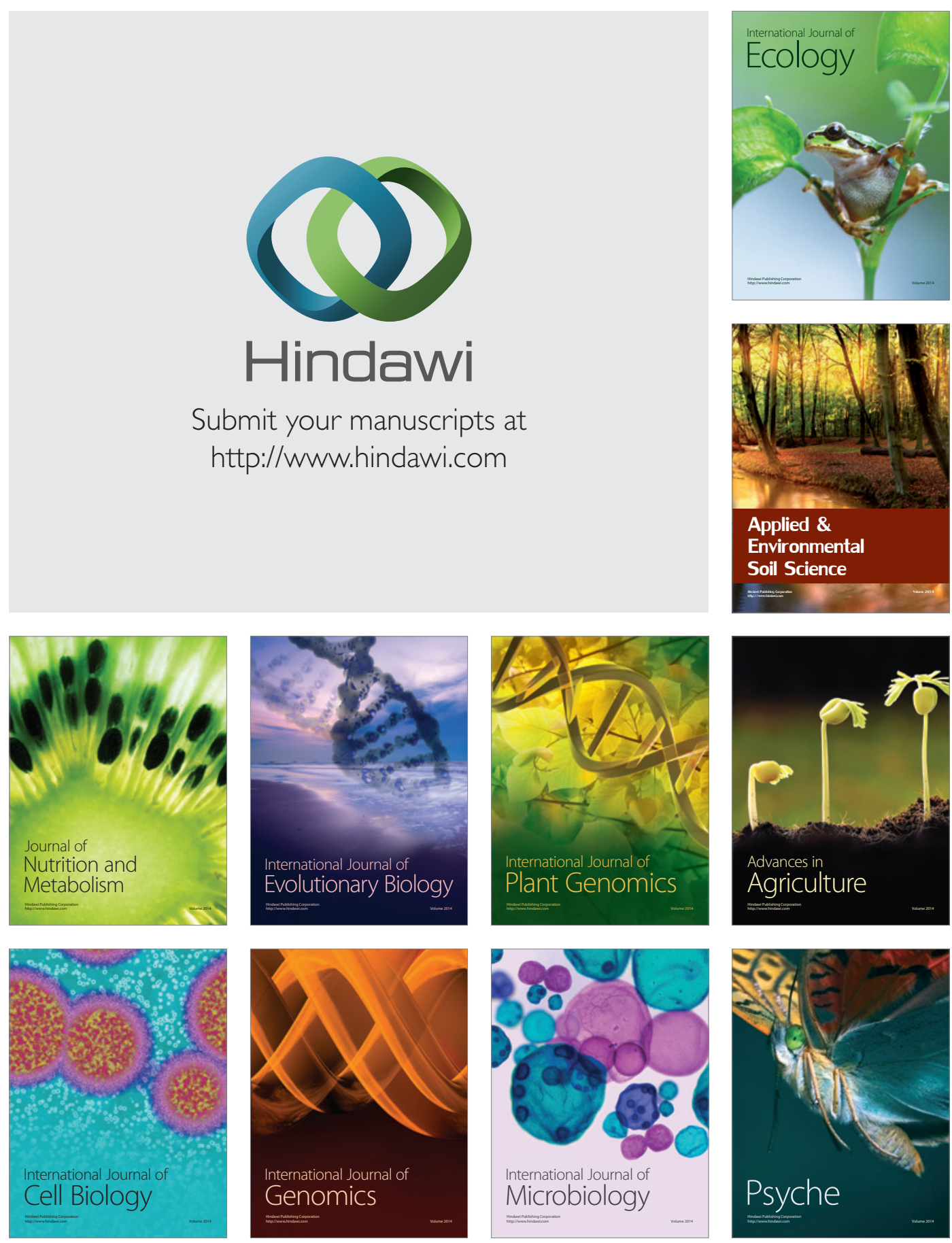